\title{
The Limits of State Intervention: Personal Identity and Ultra-Risky Actions*
}

In his Essay on Liberty, ${ }^{1}$ John Stuart Mill set forth "one very simple principle ... to govern absolutely" 2 the state's interference in the affairs of the individual:

That principle is, that the sole end for which mankind are warranted, individually or collectively, in interfering with the liberty of action of any of their number, is self-protection. That the only purpose for which power can be rightfully exercised over any member of a civilised community, against his will, is to prevent harm to others. His own good, either physical or moral, is not a sufficient warrant. ${ }^{3}$

The limits to state intervention set by Mill depend on a distinction between self-regarding actions and other-regarding actions-actions which harm only the actor, as opposed to actions which may also harm other persons. ${ }^{4}$ Mill's "liberty principle" categorically precludes state control of self-regarding actions, but permits the regulation of otherregarding actions.

Political theorists, including those sympathetic to Mill, have commonly expressed doubt whether a valid liberty principle can be so absolute..$^{5}$ These doubts focus on self-regarding actions that impose a very high risk of harm on the actor. ${ }^{6}$ In particular, when the risk of

* The author wishes to thank Professor Bruce A. Ackerman for his valuable comments on earlier drafts.

1. J.S. Mill, Essay on Liberty, in ON Liberty and Considerations on Representative Government 1 (R. McCallum ed. 1946) [hereinafter cited as ON Liberty].

2. Id. at 8 .

3. Id.

4. Mill first used the term "self-regarding" in Essay on Liberty, published in 1859. See ON LiBerTY, supra note 1 , at 73,87,88. The notion of other-regarding actions ("acts which regard others") as the opposite of self-regarding actions seems to have been introduced by James Fitzjames Stephen in LIBERTY, Equality, Fraternity 28 (R. White ed. 1967), written in 1873 as a response to Mill's essay.

5. See, e.g., H.L.A. Hart, LAw, Liberty and Morality 30 (1963); Bedau, Are There Really "Crimes without Victims"?, in E. Schur \& H. BEDAU, Victimless Crimes 55, 84 (1974); Dworkin, Paternalism, in Morality aNd THE LAw 107 (R. Wasserstrom ed. 1971); Regan, Justifications for Paternalism, in NOMOS XV-THE LIMITS of LAw 189 (J. Pennock \& J. Chapman eds. 1974); Feinberg, Legal Paternalism, I CaN. J. Phil. 105 (1971); Sartorius, The Enforcement of Morality, 81 YALE L.J. 891, 904-05 (1972).

6. The use of narcotics or other dangerous drugs is an action which the theorists generally deem self-regarding, and yet feel should be subject to state control. Sce, e.g., H.L.A. HART, stupra note 5, at 32; Dworkin, sutpra note 5, at 122. 
harm can be significantly reduced with little effort or sacrifice on the actor's part, it seems unreasonable ${ }^{7}$ to insist that the state can take no measures to protect him from the consequences of his own neglect. Jurists have shared the doubts of political philosophers about the reasonableness of Mill's absolute prohibition. ${ }^{8}$

As justification for regulating ultra-risky activities, jurists have argued that risky actions place persons other than the actor in danger and hence are truly other-regarding. ${ }^{9}$ The political theorists have concentrated instead on the actor, contending that any person who undertakes an ultra-risky activity is necessarily irrational; ${ }^{10}$ it is this lack of responsible capacity which makes Mill's principle inapplicable.

Both approaches may appear to leave Mill's principle absolute. But in effect they render it useless as a limit on state intervention. For all risky actions place some burden on others, and all risky actions can be said to attest to the irrationality of the actor. This Note offers a justification for legislation controlling ultra-risky activities that is consistent with Mill's absolute prohibition against paternalism, ${ }^{11}$ and yet does not allow unlimited state intervention. Central to the approach is the philosophical issue of personal identity.

7. The conflict between the reasonableness of such legislation and the absolute nature of Mill's liberty principle is illustrative of a general tension which exists between the utilitarian aspects and the libertarian aspects of Mill's theory. After setting forth his "simple principle" in ON LIBERTY, supra note 1 , at 9 , Mill states:

I forego any advantage which could be derived to my argument from the idea of abstract right, as a thing independent of utility. I regard utility as the ultimate appeal on all ethical questions....

See Dworkin, supra note 5 , at 117.

8. See, e.g., Winters v. Miller, 446 F.2d 65, 73-74 (2d Cir.) (Moore, J., dissenting in part and concurring in part), cert. denied, 404 U.S. 985 (1971) (medication by hospital of mentally ill Christian Scientist without her consent did not deny her First Amendment rights, even though she had not been judged legally incompetent); State v. Eitel, 227 So. 2d 489, 491 (Fla. 1969) (laws requiring wearing of motorcycle crash helmets are valid exercise of state's police power); cf. Paris Adult Theatre I v. Slaton, 413 U.S. 49, 68 \& n.15 (1973) (upholding state's right to regulate commerce in obscene material and other activities involving only consenting adults); United States v. Moore, 486 F.2d 1139, 1201 n.152 (D.C. Cir.) (concurring opinion), cert. denied, 414 U.S. 980 (1973) (upholding laws prohibiting heroin possession, but citing with approval recommendations to legalize pos. session of marijuana); United States v. Dellapia, 433 F.2d 1252, 1257 \& n.23 (2d Cir. 1970) (striking down prohibition of private distribution of obscene materials). For a discussion of courts' use of Mill's principle as a limit on state regulation, see Note, Limiting the State's Police Power: Judicial Reaction to John Stuart Mill, 37 U. CHI. L. REv. 605 (1970).

9. See cases cited in notes 31 \& 34 infra.

10. See, e.g., Dworkin, supra note 5, at 120-22; cf. C. Fried, An Anatomy of Values 159 (1970). Fried does not address Mill directly, but his argument that discounting one's future interests is irrational implies serere limits on the liberty principle.

11. The concept of paternalism as used by political theorists denotes state control over the individual to protect him from self-inflicted harm. See, e.g., Dworkin, supra note 5, at 108; Feinberg, supra note 5, at 105. 


\section{Self-Regarding Action and the Concept of a Life Plan}

A major criticism leveled against Mill is that the set of self-regarding actions is an empty set, in that every human action affects other persons. ${ }^{12}$ This criticism, however, misses the mark. Mill was not interested in whether a particular action merely affected another person, but in whether it "harmed" another. ${ }^{13}$ Absent that condition, the action is self-regarding and is protected by the liberty principle. Mill suggests that one individual harms another when he impairs the other's "self-interest"14 and the impairment infringes recognized "rights."

[T]he fact of living in society renders it indispensable that each should be bound to observe a certain line of conduct towards the rest. This conduct consists, first, in not injuring the interests of one another; or rather certain interests, which, either by express legal provision or by tacit understanding, ought to be considered as rights $\ldots . .^{15}$

Accordingly, the necessary inquiry is what is to be deemed in an individual's self-interest, and what parts of self-interest are considered to be rights.

Though Mill never explicitly defines self-interest, his theory suggests that an individual's self-interest is a matter of personally chosen values and goals. ${ }^{16}$

[Human liberty] requires liberty of tastes and pursuits; of framing the plan of our life to suit our own character; of doing as we like, subject to such consequences as may follow: without impediment

12. See, e.g., E. Barker, Principles of Social \& Political Theory 217 (1951); R. Maciver, Modern State 457-59 (1926). In Winters v. Miller, 446 F.2d 65 (2d Cir.), cert. denied, 404 U.S. 985 (1971), Judge Moore noted in dissent:

The Millsian distinction between instances of harm to others and instances of harm solely to self, relied on by the majority, would seem rarely if ever to be relevant in actuality because others are affected by virtually any action which an individual takes or fails to take.

Id. at 73-74. Mill recognized and answered this line of criticism: "When I say [affects] only himself, I mean directly, and in the first instance; for whatever affects himself, may affect others through himself . . . ON ON LIBERTY, supra note 1, at 10-11; see id. at $72-73$.

13. The term is used by Mill. ON LiberTy, supra note 1 , at 8,11 .

14. See Rees, $A$ Re-Reading of Mill on Liberty, 8 PoL. Stud. 113, 118 (1960); J. FeiNberg, Social Philosophy 25-26 (1973).

15. ON LIBERTY, supra note 1 , at $66 \cdot 67$.

16. Values and goals are the constituents of self-interest because they embody the range of reasons for which intentional human action is undertaken. When an action is undertaken to achieve some end, the action is merely instrumental to that goal. In contrast, when an action is undertaken because it is satisfying in itself, the performance of the action embodies a value. Such an action is intrinsically worthwhile to the individual though it does not further any particular goal. Many actions reflect both values and goals. For a general discussion, see C. FRIED, stupra note 10, at 7-39. 
from our fellow-creatures, so long as what we do does not harm them, even though they should think our conduct foolish, perverse, or wrong. ${ }^{17}$

Self-interest is not the equivalent of a person's fleeting, momentary desire. It is deliberate and reflective, a point which Mill makes by introducing the concept of a life-plan, "the plan of our life [framed] to suit our own character." 18 The values and goals which constitute one's life-plan are not capriciously chosen, but are fundamental aims, arranged by each individual into a system. Such arrangement can take place only after careful scrutiny. ${ }^{19}$

However, not every value and goal constituting a person's selfinterest will be protected by the state against infringement. ${ }^{20}$ The state protects only those interests "which, either by express legal provision or by tacit understanding, ought to be considered [a right]." 21 What Mill suggests is that there is an outer boundary, determined by the existing institutional structure of society, ${ }^{22}$ which limits when the

17. ON LiBerTy, supia note 1 , at 11 .

18. The concept of a life plan has been adopted by numerous philosophers since Mill. See, e.g., J. Royce, The Philosophy of Loyalty 168-69 (1908):

[T] man mentions his calling, and so actually sets out upon the definition of his purposes and of the way in which these purposes get expressed in his life. . .

... I should say that a person, an individual self, may be defined as a human life lived according to a plan. If a man could live with no plan at all, purposelessly and quite passively, he would in so far be an organism, and also, if you choose, he would be a psychological specimen, but he would be no personality. Wherever there is personality, there are purposes worked out in life.

In addition, sce Fried, supra note 10, at 99; J. RAwLs, A Theory of Justice 408-09 (1971).

19. He who lets the world, or his own portion of it, choose his plan of life for him, has no need of any other faculty than the ape-like one of imitation. He who chooses his plan for himself, employs all his faculties. He must use observation to see, reasoning and judgment to foresee, activity to gather materials for decision, discrimination to decide, and when he has decided, firmness and self-control to hold to his deliberate decision.

ON LIBERTY, supra note 1 , at 52.

20. The acts of an individual may be hurtful to others, or wanting in due consideration for their welfare, without going to the length of violating any of their constituted rights.

Id. at 67 .

[I]t must by no means be supposed, because damage, or probability of damage, to the interests of others, can alone justify the interference of society, that therefore it always does justify such interference. In many cases, an individual, in pursuing a legitimate object, necessarily and therefore legitimately causes pain or loss to others, or intercepts a good which they had a reasonable hope of obtaining.

Id. at 84 .

21. Id. at 67 .

22. When viewed in this manner, Mill's liberty principle parallels a movement in modern jurisprudence expounded by scholars such as Ronald Dworkin and Harry Wellington which might be referred to as the "rights thesis." See Dworkin, Hard Cases, 88 H.ARv. L. REv. 1057, 1058 (1975); Dworkin, The Model of Rules, 35 U. CHr. L. REv. 14 (1967); Wellington, Common Law Rules and Constitutional Double Standards: Some 
state will intervene to protect an individual's claimed self-interest. Only actions which interfere with these societally-determined rights are considered other-regarding.

Mill offers several instances in which another person's self-interest is damaged, but nonetheless that person is not deemed harmed.

Whoever succeeds in an overcrowded profession, or in a competitive examination; whoever is preferred to another in any contest for an object which both desire, reaps benefit from the loss of others, from their wasted exertion and their disappointment. . . . [S]ociety admits no right, either legal or moral, in the disappointed competitors to immunity from this kind of suffering $\ldots . .{ }^{23}$

Other actions may be harder to classify as other-regarding or selfregarding under Mill's theory because it is debatable whether or not they involve a type of injury to others cognizable under the conventions of the society. ${ }^{24}$ This is unimportant for purposes of this Note, however, for the ultra-risky actions of concern here are not at the perimeter of self-regarding actions, but at the core. These actions lack significant impact on other persons despite a high risk of serious harm to the actor. ${ }^{25}$

\section{Regulating Self-Regarding Action: Motorcycle Helmet Statutes}

Occasionally courts are faced with challenges to governmental regulations based on the claim that the regulated action is self-regarding. Such challenges, based on grounds of substantive due process, have

Notes on Adjudication, 83 YALE L.J. 221 (1973). The rights thesis argues that an individual's rights against the state are grounded in the deep premises of the society's legal institutions. Constitutive of these legal institutions are not only the statutory rules set down by the legislature and judicial precedent established by the courts (both of which Mill refers to as "express legal provision"), but also the political and moral principles which underlie the more explicit rules (Mill's "tacit understanding"). It is within the bounds of these explicit and implicit legal norms that a judge determines which self-interests are recognized as rights and accordingly protected by the state. Because political and moral principles as well as statutes and precedent are the sources of rights under the rights thesis, a court's decision as to whether an individual has a right in a particular instance is not merely a reflection of majoritarian political choice.

As made clear in the introduction to ON LIBERTX, supra note 1, at 2-3, Mill's primary concern was with liberal societies which valued self-determination. Accordingly, among the political principles which determine rights, high value will be given to individual liberty.

23. ON LIBERTY, supra note 1 , at 84-85.

24. See id, at 73 .

25. Examples include helmetless motorcycling, driving without wearing seat belts, water skiing without a life preserver, hang gliding, parachuting, mountain climbing, hunting in dull-colored clothes, swimming in heavy surf while life guards are not on duty, cigarette smoking, using narcotics, refusals to have blood transfusions, and suicide. 
been raised with respect to statutes ${ }^{26}$ requiring motorcyclists to wear protective helmets. These cases have been the subject of much discussion, ${ }^{27}$ and the merits of individual decisions need not be considered. Rather, several patterns of justification will be examined.

With few exceptions, ${ }^{28}$ the state courts deciding helmet cases have turned to the "reasonable relationship" test as the proper standard for decision. By this test, a statute based on the police power must bear a real and substantial relationship to the protection of public health, safety, or welfare. ${ }^{2 \theta}$ Such a distinction between action which affects the public welfare and action which does not in effect parallels Mill's other-regarding, self-regarding distinction.

In several cases, the courts held that the helmet laws had no effect on the public welfare and were invalid. ${ }^{30}$ The majority of state courts

26. See N.Y. Ver. \& Traf. LAw § 381(6) (McKinney 1970); Comment, State's Power to Require an Individual to Protect Himself, 26 WASH. \& LEE L. REv. 112, 112-13 n.5 (1969) (listing of state statutes requiring motorcycle crash helmets).

27. See, e.g., Comment, Constitutionality of Mandatory Motorcycle Helmet Legislation, 73 Dick. L. REV. 100 (1969); Note, Motorcycle Felmets and the Constitutionality of Self-Protective Legislation, 30 OHIo ST. L.J. 355 (1969); Comment, State's Power to Require an Individual to Protect Himself, 26 WASH. \& LEE REv. 112 (1969); 67 Mich. L. REv. 360 (1968).

28. E.g., State v. Eitel, 227 So. 2d 489 (Fla. 1968).

29. The state courts have differed from federal courts in dealing with constitutional challenges to statutes based on the police power. By inquiring whether the challenged statute protects the welfare of persons other than the individual to whom the regulation is applied, the state courts have given force to a very broad distinction between the public interest and strictly private interests. Protection of the latter has been found an inadequate justification for state interference.

In contrast, when the Supreme Court has invalidated police power statutes, it has usually held that the statute violated a more narrowly characterized right of the individual. See, e.g., Griswold v. Connecticut, 381 U.S. 479 (1965) (Connecticut statute prohibiting use of contraceptives violates constitutional right of privacy in marriage relationship); Eisenstadt v. Baird, 405 U.S. 438 (1972) (statute allowing distribution of contraceptives to married persons but not to unmarried persons denies equal protection); Roe v. Wade, 410 U.S. 113 (1973) (Fourteenth Amendment due process clause protects right to privacy, including a woman's qualified right to terminate pregnancy). When the Supreme Court has validated statutes, it has often stated that the challenged statute bears a rational relation to the public health, safety, or welfare. See, e.g., West Coast Hotel Co. v. Parrish, 300 U.S. 379, 391 (1937); Cusack Co. v. City of Chicago, 242 U.S. 526, 531 (1917); Jacobson v. Massachusetts, 197 U.S. 11, 31 (1905); Lawton v. Steele, 152 U.S. 133, 137 (1894); Mugler v. Kansas, 123 U,S. 623, 661 (1887). The weak negative pregnant of such a standard is that if the statute in question were to bear no such rational relation to the public welfare, but bore a relationship only to the private interest of the person whose actions are restrained, the statute would be unconstitutional. This negative implication might be thought of as a broad test for substantive due process.

30. E.g., People v. Fries, 42 Ill. 2d 446, 450, 250 N.E.2d 149, 151 (1969) ("The manifest function of the headgear requirement in issue is to safeguard the person wearing it ... from head injuries. Such a laudable purpose, however, cannot justify the regulation of what is essentially a matter of personal safety:"); State v. Betts, 21 Ohio Misc. 175, 184, 252 N.E.2d 866, 872 (1969) ("Whether or not a motorcyclist wears a helmet and goggles is a matter of concern solely to the individual involved. Included in man's 'liberty' is the freedom to be foolish, foolhardy or reckless as he may wish, so long as 
found, however, that the statutes did affect the interests of others. Two types of justifications were offered in support of this assertion. The first type, which will be called the "direct causal justification," suggests that a motorcyclist's refusal to wear a helmet can directly involve others on the highway in accidents. ${ }^{31}$ The court in People v. Bielmeyer $^{32}$ argued, for instance, that a motorcycle driver might be hit by insects or road gravel, causing him "to be propelled off the road or into the opposite lane causing damage to other vehicles or property or injuries to passengers or pedestrians." 33 The second type, which will be called the "indirect causal justification," suggests that although no one is directly harmed by the motorcyclist's failure to wear a helmet, the ultimate burden of an accident falls on the public. ${ }^{34}$ The court in Love v. Bell" ${ }^{35}$ argued that "[P]ersons often become public charges because of their prolonged hospitalization for serious injury, and families are often required to be supported by public welfare as a result of the death of their breadwinner." 36

Though the majority of the courts deciding the helmet cases accepted the self-regarding, other-regarding distinction implied by the reasonable relationship test, they did not offer persuasive justifica-

others are not endangered thereby."); Everhardt v. City of New Orleans, 208 So. 2d 423, 426 (La. App.), rev'd, 253 La. 285, 217 So. 2d 400 (1968), appeal dismissed and cert. denied, 395 U.S. 212 (1969) ("[W]ithout a valid benefit flowing to the public generally, an ordinance restricting a personal liberty of the individual is in contravention [of] the individual guaranties safeguarded by the due process clause."); American Motorcycle Ass'n v. State Police, 11 Mich. App. 351, 358, 158 N.W.2d 72, 76 (1968) ("This statute has a relationship to the protection of the individual motorcyclist from himself, but not to the public health, safety, and welfare."); People v. Carmichael, 53 Misc. 2d 584, 589, 279 N.Y.S.2d 272, 277-78 (Ct. Spec. Sess. 1967), rev'd, 56 Misc. 2d 388, 288 N.Y.S.2d 931 (County Ct. 1968) ("To hold that a citizen may be required to protect his health alone would be an enlargement of the police power beyond traditional limits; it would introduce a novel basis for government power, a new principle upon which to authorize the regulation of the lives of the citizen in a manner and to an extent hitherto unknown."); cf. People v. Smallwood, 52 Misc. 2d 1027, 277 N.Y.S.2d 429 (Ct. Spec. Sess. 1967).

31. See, e.g., State v. Also, 11 Ariz. App. 227, 229, 463 P.2d 122, 124 (1969); City of Wichita v. White, 205 Kan. 408, 410, 469 P.2d 287, 290 (1970); People v. Bielmeyer, 54 Misc. 2d 466, 282 N.Y.S.2d 797 (City Ct. 1967); People v. Schmidt, 54 Misc. $2 d$ 702, 705, 283 N.Y.S.2d 290, 292 (County Ct. 1967), appeal dismissed, 23 N.Y.2d 686, 295 N.Y.S.2d 936, 243 N.E.2d 153 (1968); State v. Fetterly, 254 Or. 47, 456 P.2d 996 (1969); State ex rel. Colvin v. Lombardi, 104 R.I. 28, 31, 241 A.2d 625, 627 (1968); Bisenius v. Karns, 42 Wis. 2d 42, 45, 165 N.W.2d 377, 380, appeal dismissed, 395 U.S. 709 (1969).

32. 54 Misc. 2d 466, 282 N.Y.S.2d 797 (City Ct. 1967).

33. Id. at 469,282 N.Y.S.2d at 800.

34. See, e.g., Love v. Bell, 465 P.2d 118 (Colo. 1970); State v. Lee, 51 Hawaii 516, 521, 465 P.2d 573, 577 (1970); State v. Albertson, 93 Idaho 640, 643, 470 P.2d 300, 303 (1970); State v. Anderson, 3 N.C. App. 124, 127, 164 S.E.2d 48, 51 (1968), aff'd, 275 N.C. 168, 166 S.E.2d 49 (1969); State v. Acker, 26 Utah 2d 104, 106, 485 P.2d 1038, 1039 (1971); State v. Laitinen, 77 Wash. 2d 130, 134, 459 P.2d 789, 791-92, cert. denied, 397 U.S. 1055 (1969).

35. 465 P.2d 118 (Colo. 1970).

36. Id. at 121 . 
tion for considering the failure to wear a helmet to be an otherregarding action. The direct causal justification is of uncertain validity, for no convincing empirical data has been presented by any court to show a relationship between failure to wear a helmet and the involvement of others in highway accidents. ${ }^{37}$ The indirect causal justification offers no suitable line for the domain of other-regarding actions because it allows state intervention without limit. As the court noted in People v. Carmichael: ${ }^{38}$

It can be argued that the statute here questioned affects public welfare because if a person suffers injury that could have been avoided by wearing a protective helmet, that person will perhaps become a public charge .... The possibility and even likelihood of this happening cannot be denied. If a statute required every person to refrain from smoking there could be no serious argument that many persons would be spared crippling illnesses that cause premature disability and death. If a statute required every person to retire to bed by 10:00 p.m. every evening it would probably benefit the general health of many citizens. ${ }^{30}$

The helmet cases illustrate a difficulty faced by judges, legislators, and political theorists in dealing with other legislation which seems equally reasonable yet controls action having no significant effect on other persons. Laws requiring water skiers to wear life preservers ${ }^{40}$ or hunters to wear brightly colored jackets, ${ }^{41}$ proposals to forbid hang

37. See, e.g., 67 Mick. L. Rev. 360, 368-69 (1968). The court in Love v. Bell, 465 P.2d 118, 122 (Colo. 1970), did present a statistic which might seem to establish such a relationship:

We consider it significant that Exhibit 3 submitted to the district judge by the defendant indicates that of 10,800 motorcycle accidents studied from 1962-1966, 71.7 percent of the accidents involved collision between the motorcycle and another motor vehicle.

But this statistic fails to achieve its purpose. If most of these accidents were caused by tire blow-outs, then the helmet requirement is unrelated to preventing harm to other motorists. The type of statistic needed to support the direct causal theory is one which shows that helmetless riders have accidents more frequently. No court has offered such a statistic.

Of course, in treating a constitutional challenge to a statute, there is a presumption that the factual suppositions of the legislature are valid and the statute rational, until evidence is presented to the contrary. See O'Gorman \& Young, Inc. v. Hartford Fire Ins. Co., 282 U.S. 251, 257-58 (1931). However, this Note is primarily concerned with the philosophical justification for such statutes, a matter not settled by rules of constitutional construction. In any event, it has been argued that where contrary evidence would consist of a negative fact (e.g., that helmets have no relation to the public welfare), the burden of going forward with evidence should initially be upon the state. See 67 Mirch. L. REv. 360, 369-70 (1968).

38. 53 Misc. 2d 584, 279 N.Y.S.2d 272 (Ct. Spec. Sess. 1967), rev'd, 56 Misc. 2d 388, 288

N.Y.S.2d 931 (County Ct. 1968).

39. Id. at 588,279 N.Y.S.2d at 277.

40. E.g., N.Y. NAv. LAw $\S 73(3)$ (McKinney Supp. 1975-76).

41. E.g., Wis. STAT. ANN. \$ 29.22(2) (1973). 
gliding, ${ }^{42}$ and laws making attempted suicide a criminal offense ${ }^{43}$ each present a similar dilemma. A path out is suggested by the philosophy of personal identity.

\section{Personal Identity and Mill's Liberty Principle}

Thus far this Note has concentrated on Mill's theory justifying state interference with actions which threaten harm to spatially distinct persons. These actions have been referred to as other-regarding. But the focus of a Millian analysis can be shifted radically to show that there is a whole other class of actions which are other-regarding-by considering the intertemporal effects of an individual's ultra-risky action on his own future life. This Note will contend that in certain instances an individual's ultra-risky action can be deemed otherregarding with respect to the "future selves" of that person. Mill's principle can justify state control over the person's action because it threatens harm to "other persons"-the selves he may become in the future.

To understand this approach it is necessary to consider the philosophical issue of personal identity. The theory of personal identity is concerned with how an individual is reidentified over time as the same person.

To reidentify someone is to say or imply that in spite of a lapse of time and the changes it may have wrought, the person before us now is the same as the person we knew before. ${ }^{44}$

We usually turn to physical criteria in reidentifying a person. A physical resemblance between the person at whom we are looking and

42. See Newman, The Soaring Risk of Flying High, SPORTs ILLusTrated, Nov. 24, 1975, at 85, 86 (National Park Service proposal to ban hang gliding from federally owned parks).

43. E.g., OkLa. Stat. ANn. tit. 21, \$ 812 (1958).

44. Penelhum, Personal Identity, in 6 Encyclopedia of Philosophy 95 (P. Edwards ed. 1967). Important contemporary works on personal identity include T. PENelhum, Survival and Disembodied Existence (1970); S. Shofmaker, Self-KNowledge and SelF. Identity (1963); D. Wiggins, Identity and Spatio-Temporal Continuity (1967); B. Williams, Problems of the Self (1973). For more classical discussions of personal identity, see D. Hume, A Treatise on Human Nature, Bk. 1, pt. IV, § 6, at 229 (E. Mossner ed. 1969) ; J. Locke, Essay Concerning Human Understanding, Bk. II, ch. 27, at 439 (A. Fraser ed. 1894).

That personal identity can in fact be a problem, and that questions of reidentification do arise, is illustrated by the person who has been in a serious accident and has suffered amnesia or brain damage. If the person cannot remember the major facts of his past life or cannot recognize the members of his family, we would be inclined to wonder whether he is really the same person that he was before. If the person does in fact slowly regain his memory, we would be likely to conclude: "He wasn't himself." But if the individual were never to regain memory of his past we might generally agree that he was a different person. The philosophy of personal identity is concerned with the principles upon which this judgment would be based. 
someone at whom we looked at an earlier time may serve to reidentify that person. However, psychological characteristics such as memory ultimately may be more determinative in reidentifying a person over time. ${ }^{4 \overline{5}}$ One psychological characteristic relevant to the process of reidentification is a person's life plan.

Once the characteristics relevant to identity are established, it is necessary to propose a theory which explains how these characteristics can be used to reidentify a person. Two such theories will be considered, referred to as the simple and complex views of identity. ${ }^{46}$ The simple view concludes that though a person's physical and psychological characteristics are constantly changing, nevertheless it is meaningful to say that a person has the same identity throughout his life, barring some accident which would produce permanent amnesia. In contrast, the complex view involves a more careful consideration of changes in psychological characteristics; if certain changes occur, the complex view concludes that a person's identity has changed.

\section{A. The Simple View of Identity}

Many philosophers have sought a theory of identity which would view an individual as the same person over a lifetime despite the fact that the individual's psychological characteristics, such as memory, life plans, and personality traits, can and do change. The simple view of

45. An instance in which one would rely on psychological characteristics almost to the exclusion of physical characteristics is the following: Assume $A$ is approached by an unfamiliar-looking individual who insists that he is $A$ 's old friend $B$, whom $A$ knew as a child. $A$ could test the claim by discovering whether $B$ could recollect certain events which $A$ remembered as common to both and only to both. A psychological characteristic such as memory may prove determinative even in the absence of identifying physical characteristics.

Another example lies in the "puzzle case" of a hypothetical brain transplant. (In discussing personal identity, philosophers often turn to such puzzle cases, extreme situations in which identity problems would arise.) Assume two individuals, Jones and Smith, are having their brains operated on in the same operating room and the brains are temporarily removed from their bodies. If Jones' brain is accidentally placed in Smith's body, and vice versa, what would be said about the identity of the individuals after they regained consciousness? If the individual who looks like Jones suddenly had the personality and memories of Smith, we would very likely conclude that, despite physical appearances, the person who looked like Jones was "really" Smith. This puzzle case strongly suggests that psychological characteristics such as memory and character traits play a far more important role in personal identity judgments than do physical traits. See S. Shoemaker, supra note 44, at 22-40; C. Whitely, Mind IN Action 98-113 (1973). Even under this theory of identity, it is of course necessary that the psychological traits be lodged within a physical being. See P. STRAwson, INDIviduals 81-113 (1963); D. Wigcins, supra note 44 , at 43.58 . For the view that bodily characteristics are more important than psychological characteristics, see Penelhum, supra note 44, at 103-04.

46. The terminology is borrowed from the work of Oxford philosopher Derek Parfit. See Parfit, On "The Importance of Self-Identity", 68 J. PHIL. 683, 684 (1972) [hereinafter cited as Importance]; Parfit, Later Selves and Moral Principles, in PhiLosophy AND Personal Relations 137, 138 (A. Montefiore ed., 1973) [hereinafter cited as Later Selves]. 
identity meets this goal. On this view, the crucial criterion of identity is psychological continuity-the constant overlap of psychological traits over a person's lifetime. Though a 60-year-old has no common memories or goals with the person he was at 10 years of age, under the simple view this fact is unimportant for the conclusion that the two persons are identical. The 60-year-old does have common memories and goals with the self he was at 55. In turn, the self at 55 had common memories and goals with the self at 50 . This chainlike linking of psychological characteristics continues back until the man was 10 years old, unless in the interim there has been some amnesia-producing event. If no such permanent break has occurred, any two selves along the chain can, by regress, be said to be identical.47

A Millian who adopts the simple view of identity would relate it to the liberty principle in the following way: irrespective of whether an individual shares common psychological characteristics with the person that he was at some earlier time in his life, nonetheless he is psychologically continuous with the earlier person, and thus they are identical. ${ }^{48}$ Hence, when a 20-year-old performs some action which involves a serious risk of harm to himself, the action is self-regarding. ${ }^{40}$ This is so whether the harm will accrue immediately or only in 40 years.

Yet this conclusion ignores a serious tension between the simple view of identity and the basic premise of Mill's liberty principle. Mill justified his liberty principle by arguing that each person is likely to be the best guardian of his own interests. ${ }^{50}$ But if it can be predicted

47. A clear statement of this view is offered by Anthony Quinton:

People's characters change; some memories are lost and new ones are acquired. What is clearly required [for identity] is continuity. A person could be said to be directly continuous with a person existing at an earlier time provided that the characters of the two are closely similar and that the later person can recollect the bulk of what the earlier person can. Two persons are indirectly continuous if there is a series of persons at intervening times who are each directly continuous with their neighbours in the series and if the two original persons are respectively directly continuous with the latest and earliest members of the series. $A$, then, is the same person as $B$ if either is directly or indirectly continuous, in the senses defined, with the other.

A. Quinton, The Nature of Things 96 (1972). This view differs slightly from Parfit's notion of the simple view. See Later Selves, supra note 46, at 140 .

48. It is assumed throughout the discussion that no event such as an amnesiaproducing accident has occurred to break the continuity.

49. Thus cigarette smoking would be a self-regarding activity because, under the simple view of identity, any disease occurring later in life affects the same person.

50. But neither one person, nor any number of persons, is warranted in saying to another human creature of ripe years, that he shall not do with his life for his own benefit what he chooses to do with it. He is the person most interested in his own well-being . . . [W]ith respect to his own feelings and circumstances, the most ordinary man or woman has means of knowledge immeasurably surpassing those that can be possessed by any one else. The interference of society to overrule his judg. 
that as a result of his present actions a person's goals and values will change drastically, there is less reason to believe that the person himself is the best guardian of his future interests. For in undertaking his present action, he may not be acting in accord with the same values, perhaps not even the same life plan, that he will have at some future time. Such a prediction of changed values can be made when an individual undertakes an action entailing very high risk of serious physical harm. A severe physical injury such as brain damage or laming will force an individual to change the way he views his life and lead him to adopt differing values and goals that better accord with his physical change. Medical and psychological literature offers some support for the hypothesis that the psychic trauma resulting from a serious accident leads a person to disidentify with his older goals, ${ }^{51}$ perhaps sufficiently to constitute a change in life plan. In such an instance, a philosopher holding a simple view of identity can justify intervention but in doing so is forced to abandon Mill's absolute liberty principle: the state is justified in intervening but only because the individual is

ment and purposes in what only regards himself must be grounded on general presumptions; which may be altogether wrong, and even if right, are as likely as not to be misapplied to individual cases ....

ON LIBERTY, supra note 1, at 68.

[T] purely personal conduct is that, when it does interfere, the odds are that it interferes wrongly, and in the wrong place.

Id. at 74 .

51. Though there is extensive medical literature related to the physical effects of traumatic accidents, literature analyzing the psychic effects of such accidents is considerably less available. Krystal and Petty note that in later stages of convalescence after serious physical injury,

denial [of the illness gives] way to grieving involved in the decathexis of the lost parts of the previous body image, allowing for a modification of self-representation in such a way as to permit the greatest possible satisfaction under the new circumstances.

Rehabilitation in Trauma Following Illness, Physical Injury and Massive Personality Damage-The Psychological Complications of Convalescense, in Massive Psychic Trauma 281 (H. Krystal ed. 1968). This "modification of self-representation" amounts to a change in an individual's conception of himself. "The outcome of normal convalescence is to form a new self-representation .... that is, the addition of the illness and its effects to the former image of the self together with the surrender of the lost function and/or parts." Id. at 282. In adapting to the impaired function resulting from the serere accident, it seems likely that the injured person will adopt a more conservative life plan to better accord with his lessened ability.

Other authors have described a "posttraumatic syndrome" following serious head injuries, characterized by impaired memory, irritability, inability to concentrate, excessive fatigue, headaches, and vertigo. E.g., A. WALker \& F. ERculei, Head InJurkd MfenFifteen Years Later 44 (1969); Caveness, Posttraumatic Sequelae, in HEAd INJURYConference Proceedings 209 (W. Caveness \& A. Walker eds. 1966). These symptoms, impairing an individual's functioning after the accident, would probably lead him to shy away from brash actions. A. Walker \& F. Erculei, supra at 56. Cf. Psychic Trauma (S. Furst ed. 1967). 
no longer considered the best guardian of his own self-interest. ${ }^{22}$

Political theorists have proposed a resolution to this tension between Mill's theory and the simple view of identity to allow retention of an absolute liberty principle. They have done this by expanding the concept of a life plan so that the future self-interest of an individualhis prudential ${ }^{33}$ interests-must be included among the values and goals of his present life plan if the life plan is to be deemed rational. Under this expanded notion, a rational life plan must have a "second tier" of principles which account for likely changes in basic values and goals over time..$^{54}$ If such prudential interests are not part of the life plan, the person is acting irrationally, ${ }^{55}$ and one can justify state regulation in the same way that state control of children is justified. ${ }^{56}$ Like

52. One justification for social security legislation is that a person at a young age will have values and goals distinct from those he will have when he reaches retirement. The state must force him to consider his future self-interest and save money, because such considerations will not enter his present life plan.

53. See Nagel's usage of the term as referring only to the future:

In discussing prudence, we shall be concerned with the element of practical fore. sight, rather than with any special association the notion may have with self-interest. This must be mentioned because in philosophical usage the term 'prudential' has come to mean approximately the same as 'self-interested', losing even its special connection with provision for the future.

T. Nagel, The Possibility of Altruism 36 (1970).

54. See C. Fried, supra note 10, at 164:

It does not follow at all ... that provisions cannot be made for . . change in external circumstances and change in tastes, preferences, capacities, and the like. On the contrary a rational life plan must make provisions for these things. It must make provision for changes in tastes and preferences even though tastes and preferences provide the perspective from which life plans are chosen. For the life plan is correlative with the sense of personal identity, and, just as that identity, is perceived to persist in spite of such changes.

See J. RawLs, supra note 18, at 416-17.

55. See, e.g., C. FrIED, supra note 10, at 159 :

[W] may conclude that discounting the future as such is irrational, or rational only on a conception of ourselves which must be characterized as aberrant. If the satisfactions of a future self are equally important as the satisfactions of a present self, then of course it is irrational to discount the future in favor of the present.

For a view that ignoring prudential interests can be a rational way of life, see Trebilcot, Aprudentialism, 11 AM. PHIL. Q. 203 (1974).

56. Mill recognized that children are unaware of their self-interest and thus exempt from his principle:

It is, perhaps, hardly necessary to say that this doctrine is meant to apply to human beings in the maturity of their faculties. We are not speaking of children .... Those who are still in a state to require being taken care of by others, must be protected against their own actions as well as against external injury.

ON LIBERTY, supra note 1, at 9 . Included in this group of irrational persons would be the senile, those acting under great emotional stress, and those who have temporarily lost control of their bodies due to spasm or fit. One might also include individuals who possess mature faculties but are unable to evaluate a situation and act in their self-interest because of misunderstanding or ignorance of some important fact. Even Mill agreed that the state is justified in controlling this group.

If either a public officer or any one else saw a person attempting to cross a bridge which had been ascertained to be unsafe, and there were no time to warn him of 
children, irrational individuals do not know what is in their selfinterest because they lack emotional and cognitive capacities and cannot make reasoned decisions.

This notion of an expanded life plan does appear at first to reconcile the simple view of identity with Millian theory by eliminating the possibility of conflicting self-interests over time. When a person adopts a life plan which so ignores his prudential interests that it might be said that his present actions conflict with his future interests, that person is deemed irrational, and subject to state control. However, this sleight of hand is subject to fundamental difficulties.

First, it simply is not true that all individuals undertaking ultrarisky activities are necessarily irrational. Risk-taking individuals include many for whom it is a profession, whether motorcyclists, race car drivers, mountain climbers, or parachutists. To call this group irrational contradicts an equally vital premise of Mill's theory-that one should be free to choose the values and goals of one's life plan despite their eccentricity. ${ }^{67}$ Second, by deeming anyone who adopts an ultrarisky life plan irrational, one confronts a problem noted earlier ${ }^{58}$ there are no limits to state control. Any time that a person adopts a risky life plan, the state merely suggests that by not giving more heed to prudential concerns the person is irrational. The ploy of the expanded life plan is suggestive of a "real will" theory, which characterizes totalitarian political philosophy. 59

his danger, they might seize him and turn him back, without any real infringement of his liberty; for liberty consists in doing what one desires, and he does not desire to fall into the river.

Id. at 86. See generally Feinberg, supra note 5, at 105; Dworkin, supra note 5, at 120-22.

57. See ON LIBERTY, supra note 1, at 11; $i d$. at 50:

[T] here should be different experiments of living; ... free scope should be given to varieties of character, short of injury to others; and ... the worth of different modes of life should be proved practically, when any one thinks fit to try them. It is desirable, in short, that in things which do not primarily concern others, individuality should assert itself.

58. P. 833 supra.

59. See I. BerLin, Two Concepts of Liberty, in Four EssAys on Liberty 118, 133

(1969). Berlin warns of the dangers of a "real will" theory:

[I]t [is] easy for me to conceive of myself as coercing others for their own sake, in their, not my, interest. I am then claiming that I know what they truly need better than they know it themselves. . . I may [even] declare that they are actually aiming at what in their benighted state they consciously resist, because there exists within them an occult entity-their latent rational will, or their 'true' purpose-and that this entity, although it is belied by all that they overtly feel and do and say, is their 'real' self .... and that this inner spirit is the only self that deserves to have its wishes taken into account. Once I take this view, I am in a position to ignore the actual wishes of men or societies, to bully, oppress, torture them in the name, and on behalf, of their 'real' selves ....

See Dworkin, supra note 5, at 119. 


\section{B. The Complex View of Identity: An Alternative Approach}

There is an alternative view of identity, developed in the writings of Derek Parfit, ${ }^{60}$ that offers a way in which Mill's absolute liberty principle can be held intact-successfully reconciling the liberty principle with state intervention in the case of individuals undertaking ultra-risky actions.

The simple view of identity looked to continuity of psychological characteristics in order to reidentify a person over time. A change in psychological characteristics (including a change in life plans) was of little significance to the simple view, so long as there existed an intertemporal linking of some characteristics. In contrast, the complex view of identity looks to psychological connectedness as the basis for reidentification of a person over time. Connectedness refers to the degree of similarity between an individual's psychological characteristics at two different times in his life. ${ }^{61}$ If there is a high degree of similarity, the complex view concludes that the individual is the identical person at those two moments. But if the psychological characteristics are very different (including life plans and self-interests implied by those plans), the complex view concludes that there are two nonidentical selves. Thus, where an 18-year-old and the person he becomes at the age of 60 have similar life plans (and thus self-interests) along with other common psychological characteristics, we would consider them identical. Where, however, they have radically dissimilar life plans and self-interests, they have little psychological connectedness and under the complex view of identity would be deemed nonidentical persons. ${ }^{62}$ For purposes of this Note, where a person at an earlier time is psychologically disconnected from himself at a later time, the later person will be referred to as a "future self" of the earlier person; the person at the earlier time is referred to as a "past self" of the person at the later time. ${ }^{63}$

60. See works cited in note 46 supra; Parfit, Personal Identity, 80 PhIL. Rev. 3 (1971). The relevance of Parfit to Mill's theory has been suggested by Regan, supra note 5 , at 201-06.

61. One major difference between psychological continuity and connectedness is that the former is an all-or-nothing proposition, while the latter admits of degrees. An earlier self and a later self are psychologically continuous or they are not; either there exists a linking or there does not. In contrast, a person can be more connected or less connected to an earlier self; he can have more or fewer psychological characteristics in common with the earlier self. In the complex view, a person thus can be more identical or less identical with a former self. See Parfit, Later Selves, supra note 46, at 139.40 .

62. For a discussion of the implications of adopting the complex view of identity in the law, see $i d$. at $142-43$.

63. For the sake of simplicity the Note departs from Parfit's terminology at this point. Parfit refers to nonidentical selves over time as ancestral and descendant selves, while he reserves the terms future selves and past selves to refer to identical individuals. See Parfit, Personal Identity, supra note 60, at 21-22. 
The complex view of identity complements Mill's absolute liberty principle far better than the simple view does. If one is able to predict that in the event of serious harm resulting from a risky life plan a person will most likely disidentify with his past self by adopting a dissimilar life plan, ${ }^{64}$ the complex view of identity allows the preaccident individual to be considered nonidentical to the potential post-accident individual. The complex view of identity introduces a concept of temporal otherness, similar to the concept of spatial otherness which has characterized Mill's principle. Because the actions of an individual adopting an ultra-risky life plan threaten to harm a nonidentical person, Mill's principle would allow state intervention.

There will be instances under the complex view in which the state will not be allowed to prohibit an individual's ultra-risky actions; such instances occur when the prediction that a person is likely to disidentify cannot be made. An example may be when a person refuses medical treatment on religious grounds. ${ }^{65}$ A person might be seriously debilitated by the refusal, but if such an act most often leaves the person even more committed to his religious conviction, the refusal would be deemed a self-regarding action and beyond state control, for no major change in life plan would have occurred. Another action which would surely be deemed beyond state control under the complex view is suicide. In order for Mill's justification of state intervention to apply intertemporally, it is necessary that one make a reasonable prediction that future selves will disidentify with the present self. But where it is clear that there will be no future selves, such a predic-

64. See p. 837 supra. Ordinary language provides a vocabulary in which to draw a psychological analogy to the complex view of identity. Just as one might be asked whether he "identifies" with another person, it is also meaningful to ask whether he "identifies" with the person he was in the past. In Importance, supra note 46, at 683-84, Parfit describes what it might mean not to identify with oneself at a previous point in time in this psychological sense:

The state of mind is a kind of indifference towards a part of our lives. We are in this state of mind when, for example, there is a part of our past that we do not regard with either pride or shame, either pleasure or regret.

The state of mind can have this effect. A man may despise a certain kind of behavior. Because he does, he would be appalled if he had recently behaved in this way. But he may have no regrets at having once so behaved. He may have ceased to care about the period when he so behaved.

The man's attitude toward himself in the earlier period I shall call "nonidentification." ...

This man's attitude may have the following cause. The man may say "I admit that I behaved in that way. But the ' $Y$ ' who so behaved seems to me a stranger. What I wanted, thought, and admired-how I lived, how I tried to live-all of these are now changed." Nonidentification does not always have this kind of cause; but it often does.

65. Sce, e.g., Application of President \& Directors of Georgetown College, Inc., 331 F.2d 1000 (D.C. Cir. 1964); Erickson v. Dilgard, 44 Misc. 2d 27, 252 N.Y.S.2d 705 (Sup. Ct. 1962). 
tion becomes meaningless. Since there will be no future intertemporal "others," suicide is a purely self-regarding action. ${ }^{\text {"0 }}$

The complex view's justification for state control of ultra-risky actions avoids the now familiar problem of the other approaches-it cannot be used to rationalize limitless control of the individual. One cannot simply argue that a person's present action will affect him adversely in the future. To justify state control under Mill's liberty principle requires that a person's action threaten harm to another person. Under the complex view of identity, another self is threatened intertemporally only when there is a high risk of future disidentification as a result of present action. Therefore, the threatened harm must involve trauma so serious that, in the event such harm occurs, future selves will reject past life plans. The range of actions involving so great a risk of harm is relatively small.

At the core of the actions which can be controlled under the proposed justification are those that threaten severe physical harm such as loss of a limb, loss of sight, or permanent crippling. To adopt a liberty-restraining statute under the proposed justification, a legislature will have to be convinced not only that some harm will occur (the sole prerequisite for controlling actions which affect interspatial people), but also that the harm is of a type which will lead to intertemporal disidentification.

\section{Life-Regarding Justifications}

Once an action is deemed other-regarding and thus subject to state control, a second order question arises as to whether the state should control the action through the mechanism of law. ${ }^{67}$ After society has gained jurisdiction over an action Mill's theory becomes essentially utilitarian..$^{68}$ An individual's action is to be controlled by the state if and only if the greatest general welfare is thereby promoted. If control

66. This assumes that the decision to commit suicide has been entered into rationally. In instances in which it can be shown that the person's decision was made under duress or severe emotional tension, even Mill would allow state intervention. See note 56 supra. 67. As soon as any part of a person's conduct affects prejudicially the interests of others, society has jurisdiction over it, and the question whether the general welfare will or will not be promoted by interfering with it, becomes open to discussion.

ON LIBERTY, supra note 1 , at 67 .

68. Mill set forth his principle of utilitarianism in his essay, UTILITarianism 262 (M. Warnock ed. 1962):

According to the Greatest Happiness Principle . . . the ultimate end, with reference to and for the sake of which all other things are desirable (whether we are considering our own good or that of other people), is an existence exempt as far as possible from pain, and as rich as possible in enjoyments .... 
would not maximize the general welfare, the action should be allowed even though it may harm other persons.

To evaluate whether an action deemed intertemporally other-regarding is better left uncontrolled, several principles are useful. One is the "impact principle," equally applicable to interspatial and intertemporal other-regarding actions. This principle holds that where the impact of an action upon one person is very great, while its impact on another person is less significant, the self-interest of the first person is to be given greater consideration. ${ }^{69}$ In an intertemporal context, for an action to be deemed other-regarding in the first place, the harmful impact on future selves has to be great. Thus the state will generally be justified, in utilitarian terms, in controlling present ultra-risky actions for the sake of future selves. But at some point, when control over these actions produces a significant negative effect on the present self, it may maximize social utility to favor the interest of the present person over the interest of the future self.

A second principle which mediates between present and future selves can be referred to as the "certainty principle." While the impact principle looks to the seriousness of the harm suffered, the certainty principle looks to the risk of the potential harm. Where equal hardship might be suffered by two individuals, the individual who has a higher risk of incurring the hardship should be given greater consideration..$^{70}$ Where, if his action is controlled, a present self will suffer harm equal to the harm a future self would suffer if the action is not controlled, but the risk that the present self will suffer the harm is greater, the self-interest of the present self is to be given precedence.

One situation in which present self-interest should be preferred is when a person can give a "life-regarding justification" in favor of his present action-when he can demonstrate that fulfillment of his present life plan would be fundamentally stifled by forcing him to protect future selves. Under Mill's system, having the liberty to live out one's goals and values has great importance. For a person to claim that his life plan will be stifled is to make a claim of substantial import. When

69. The "impact principle" requires that the state be able to make interpersonal comparisons of utility. Neoclassical economists have in the past argued that such comparisons are impossible to make. See, e.g., L. RobBins, AN ESSAY on THE NATURE \& Significance of Economic Science (1952). More recently, however, it has been suggested that utility functions are in fact subject to partial comparability. See, e.g., A. SEN, Collective Choice and Soclal Welfare 99, 108 (1970).

Insofar as preference to one person's life plan can be accorded incrementally, the impact principle should be applied on a marginal basis-that is, preferring the selfinterest of the person likely to suffer the greater harm, $u p$ to the point where his suffering is reduced to the level of the suffering of others.

70. This principle applies interspatially as well. 
such interference can be shown to be certain, an individual would have a strong claim to a decision by the state in his favor as against his future selves.

The concept of a life-regarding justification can be illustrated by considering the motorcycle helmet statutes. Most individuals challenging the statutes argued that they suffered an infringement of their liberty. Yet the degree of this infringement can really be understood only when the individual's life plan is taken into account. For most people, not wearing a helmet plays a trivial part in their life plans. In a few instances, however, an individual may be able to give a liferegarding justification for not wearing a helmet. He might argue that his major satisfaction in life derives from riding his motorcycle, and that the major source of this pleasure is the exposure to the elements as he rides. Or he might argue that he is a professional motorcyclist whose reputation in exhibition riding depends on his demonstrated fearlessness.

Though the proposed test of life-regarding justification refers to intertemporal comparisons of utility, it directly parallels the sort of interspatial comparisons of utility which presently are made. In numerous instances other-regarding actions are not controlled by the state, even though those actions threaten very serious harm to spatially separate persons. The most obvious example is automobile driving. Society has decided that people will be allowed to drive automobiles even though it can be predicted with a high degree of accuracy that thousands of people will be killed, many of whom are pedestrians who do not drive cars themselves and hence inflict no reciprocal risk. Nonetheless, it has been decided that to ban cars for the sake of the lives lost would fundamentally interfere with the functioning of modern society. ${ }^{71}$

It might be claimed that the choice made in interspatially otherregarding activities is fundamentally different because it threatens harm to victims who remain anonymous until after the accident, while in intertemporally other-regarding actions we know the victim beforehand. But this is simply not true. There are a multitude of potential selves at each future moment who are as anonymous as the nameless victims whom we know statistically will be killed in automobile accidents.

How would an administrative tribunal distinguish valid life-regarding justifications from invalid ones? An answer lies in the nature of self-interest in Mill's theory. As suggested in Part $I,{ }^{72}$ Mill's theory

71. See, e.g., G. Calabresi, The Cost of Accidents 17-18 (1970).

72. See pp. 828-29 supra. 
entails a notion of self-interest in which the individual is the source of the governing values and goals. Once an individual has begun applying his values and goals to action, his self-interest begins to develop its own "history." A person's assertions as to what is in his self-interest must be considered in light of past actions. ${ }^{73}$ When a person comes before a tribunal seeking an exemption from the regulation, he would have to document the historical importance of the action in his life. ${ }^{74}$

\section{Conclusion}

In the last book of Principles of Political Economy, ${ }^{75}$ published 11 years before the Essay on Liberty, Mill analyzed the proper limits of state intervention in the marketplace and common economic life of the community. Laissez-faire, he concluded, "should be the general practice: every departure from it, unless required by some great good, is a certain evil." ${ }^{76}$ But intervention was permissible where a "great good" would be served. For instance, "the proposition that the consumer is a competent judge of the commodity" had numerous exceptions. ${ }^{77}$

Mill's acceptance of a more utilitarian approach to government intervention in the "business of the community" contrasts sharply with the absolute nature of his liberty principle, which gave full autonomy to individuals in the conduct of their own more personal lives. ${ }^{78}$ One particular discussion-a justification of the rule against contracts in perpetuity-makes the disparity all the more odd, for the passage is startlingly reminiscent of the problem of ultra-risky actions:

\section{$\mathrm{A}[\mathrm{n}]$. . . exception to the doctrine that individuals are the best} judges of their own interest, is when an individual attempts to

73. Thus, if an individual continually asserted that donating to charity was an important value to him, and yet he had never given to charity, one would suspect that the individual was merely puffing and did not in fact hold this value as part of his life plan. Of course in some instances this might not be the case; an individual might have been forced to spend all his money feeding his family or caring for a sick relative. Yet one wonders what it would possibly mean to hold a value and never to act upon that value.

74. If a person accustomed to a quiet, subdued life underwent an eye-opening experience which wholly changed his preferences and caused him to adopt an ultra-risky life plan, he would of course be unable to support his life-regarding justification with conventional historical data of other instances in which he had acted on that value. Yet such a person might have friends testify about the completeness and sincerity of his change of heart and his commitment to his new life plan.

75. J.S. Mill, Principles of Political Economy: With Some of Their Applications To Social Philosophy (W. Ashley ed. 1923).

76. Id. at 950 .

77. Id. at 953 .

78. Even in Principles of Political Economy Mill adhered to an absolute injunction against state interference with the self-regarding affairs of the individual. See id. at 943 . 
decide irrevocably now what will be best for his interest at some future and distant time. The presumption in favour of individual judgment is only legitimate, where the judgment is grounded on actual, and especially on present, personal experience; not where it is formed antecedently to experience, and not suffered to be reversed even after experience has condemned it. When persons have bound themselves by a contract, not simply to do some one thing, but to continue doing something for ever or for a prolonged period, without any power of revoking the engagement, the presumption which their perseverance in that course of conduct would otherwise raise in favour of its being advantageous to them, does not exist .... The practical maxim of leaving contracts free is not applicable without great limitations in case of engagements in perpetuity; and the law should be extremely jealous of such engagements; . . . if it ever does sanction them, it should take every possible security for their being contracted with foresight and deliberation $\ldots$. . $^{79}$

Mill never extended this exception from market laissez-faire to his liberty principle. The complex view of identity offers one way of giving effect to the prudential concerns that informed Mill's economic utilitarianism without abandoning the clarity and consequent protection of a liberty principle sounding in absolute terms.

79. Id. at 959-60. 